\title{
VAISIAUS ALKOHOLINIS SINDROMAS
}

\author{
Dovilè Bradulskaitè \\ Vilniaus universiteto Medicinos fakulteto Odontologijos institutas
}

Raktažodžiai: vaisiaus alkoholinis sindromas, alkoholis nėštumo metu, augimo sutrikimas, specifiniai veido bruožai, smegenų anomalijos.

\section{Santrauka}

Šio straipsnio tikslas atkreipti dèmesị i alkoholio vartojimo nèštumo metu keliamus pavojus ir aktyviau domètis psichiką veikiančių medžiagų poveikiu něštumo metu. Medikus, visuomenès sveikatos specialistus aktyviau prisidèti prie visuomenès švietimo, o politikus priimti sprendimus, kurie ipareigotu alkoholio gamintojus tinkamai informuoti vartotojus apie jų gaminamų produktų keliamą pavojų sveikatai. Pateikiami vaisiaus alkoholini sindromą sukeliantys veiksniai, epidemiologija, diagnostikos principai, simptomatika, atkreipiant dèmesi ị odontologinius aspektus, prevencija ir prognozè.

\section{Ivadas}

Rugsėjo 9 d. - Tarptautinè vaisiaus alkoholinio sindromo paminejjimo diena. Šios dienos paminèjimo renginiai pradedami devynios minutès po devynių ryte. Ši diena pasirinkta todèl, kad dar kartą būtų priminta, jog moteris visus devynis néštumo ménesius turi nevartoti alkoholinių gérimų. Vaisiaus alkoholinis sindromas (VAS) - protinio ir fizinio vystymosi sutrikimas, sukeliamas vartojant alkoholị néštumo metu. Alkoholis praeina pro placentos barjerą ir gali sulètinti vaisiaus augimą, veidas igauna specifinius bruožus, pažeidžiama nervų sistema [1-3].

Šio straipsnio tikslas - atkreipti dèmesị ị alkoholio vartojimo něštumo metu keliamus pavojus, aktyviau domètis psichiką veikiančių medžiagų poveikiu nėštumo metu, medikus ir visuomenès sveikatos specialistus aktyviau prisidèti prie visuomenès švietimo, o politikus kuo greičiau priimti sprendimus, kurie ịpareigotų alkoholio gamintojus tinkamai informuoti vartotojus apie jų gaminamų produktų keliamą pavojų sveikatai.

Etiologija. VAS sukelia alkoholis, vartojamas vaisiaus vystymosi metu. Nèra "saugaus" alkoholio kiekio, galimo vartoti nëštumo periodu. Didesnis išgertas alkoholio kiekis yra pavojingesnis nei mažesnis $[4,5]$, nes didesnis alkoholio kiekis sukelia didesnius vystymosi sutrikimus. Alkoholis, vartojamas pirmojo nèštumo semestro metu, sutrikdo nervinio vamzdelio ir keteros vystymąsi, todèl formuojasi mikrocefalija [6], hidrocefalija [7], akių deformacijos [8, 9] ir specifiniai veido bruožai [10]. Antrojo semestro metu alkoholio poveikyje sutrinka neuronų ir pagalbinių ląstelių (glijos) proliferacija, todèl didejja neurotropinių faktorių (pvz., (TGF)- $\beta$ ), kurie sukelia nenormalią smegenų žievès neuronų migraciją $[11,12]$. Trečiojo nèštumo semestro metu smegenys sparčiai vystosi. Tai vadinama "smegenų augimo spurtu". Šiuo laikotarpiu neuronai yra ypač jautrūs alkoholio poveikiui. Alkoholis paveikia sinapsių formavimąsi ir taip sukeliamas smegenų plastiškumas [13]. Smegenų plastiškumas, arba neuroplastiškumas, yra nervų sistemos savybè keistis, augti ir formuoti naujas jungtis dèl elgesio pokyčių, naujai igytos patirties, aplinkos, nervų sistemos procesų, fizinių sužalojimų [14].

Paplitimas. Daug literatūros šaltinių nagrinèja VAS epidemiologiją. Apibendrinant galima teigti, kad šis sindromas pasireiškia $0,6-3$ naujagimiams iš 1000 [15]. Nèra tiksliai žinomas išgerto alkoholio kiekis, nuo kurio vystosi vaisiaus sutrikimai, todèl pakankamai sunku nurodyti ribas, koks alkoholio kiekis yra rizikingas. Nustatyta, kad 15\% moterų néštumo metu vartoja alkoholį, tačiau tik $4 \%$ vartoja dideli jo kiekị. Lietuvoje alkoholio vartojimas pastaraisiais metais augo ir $2011 \mathrm{~m}$. pasieke 14,1 litro absoliutaus alkoholio vienam suaugusiam (15 metų ir vyresniam) gyventojui [32]. Tuo tarpu Švedijoje krito - 10,0 litro absoliutaus alkoholio vienam suaugusiam gyventojui. Didelę įtaką VAS paplitimui turi rizikos veiksniai, pvz.: žema socialinè - ekonominè padètis, menkas išsimokslinimas, rūkymas, narkotikų vartojimas. 2011 m. Lietuvoje vaikų skaičius socialinès rizikos šeimose siekè 22073 [16-18,33].

Diagnostika ir simptomatika. Pasaulyje naudojamos ivairos VAS diagnostinès sistemos. Labiausiai paplitusi yra The 4 - Digit Diagnostic Code sistema. Pagal šią sistemą tiriama: 1) augimo sutrikimas; 2) veido specifiniai bruožai; 3) smegenų anomalijos; 4) moters išgertas alkoholio kiekis nèštumo metu [15-19]. Šie duomenys surašomi ị The 4 - 
1 pav. The 4-Digit Diagnostic Code lentelè

\begin{tabular}{|c|c|c|}
\hline Sunkus & Sunkus & Patvirtintas \\
\hline Vidutinis & Vidutinis & Tikėtinas \\
\hline Lengvas & Lengvas & Galimas \\
\hline Nėra & Nėra & Nèra \\
\hline $\begin{array}{c}\text { Augimo } \\
\text { sutrikimas }\end{array}$ & $\begin{array}{c}\text { Specifiniai } \\
\text { veido } \\
\text { bruožai }\end{array}$ & $\begin{array}{c}\text { Smegenų } \\
\text { anomalijos }\end{array}$ \\
\hline
\end{tabular}

\begin{tabular}{|l|l|l|l|}
\hline 4 & & & \\
\hline 3 & & & \\
\hline 2 & & & \\
\hline 1 & & & \\
\hline & Augimas & Veidas & Smegenys \\
& & & \\
& & & \\
\hline
\end{tabular}
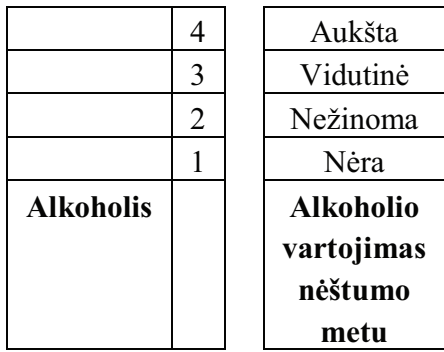

Digit Diagnostic Code lentelę, sudarytą Vašingtono universitete $[21,22,23]$.

1. Augimo sutrikimas. Vaikas, turintas VAS, yra mažo kūno svorio ir/ar ūgio [20]. Vertinimui naudojama morfologinių ir funkcinių augimo rodiklių procentilinès skalès. Taip pat reikia atkreipti dèmesị i tèvų ūgị, gestacinį amžių, blogą mitybą [17].

2. Specifiniai veido bruožai. Jiems priskiriamas lygus lūpos filtras, plona viršutinè lūpa ir siauras akių plyšys. Lūpos filtras ir viršutinè lūpa yra matuojama kartu naudojant 5 lygiu Likerto skalę ( 1 - normalus storis, 5 - sunkus nukrypimas). Akių plyšys matuojamas milimetrine liniuote (2 pav.).

3. Smegenų anomalijos. Joms įvertinti yra naudojama 5 lygių smegenų disfunkcijos skalè. Vertinama mikrocefalija, adaptacijos, pažinimo, kalbos sutrikimai, asmeninès savybès.

4. Alkoholio vartojimas néštumo metu. Moteris nèštumo metu gali išgerti didelị, mažą ar nežinomą alkoholio kiekị. Taip pat ji gali nepripažinti vartojusi alkoholị, ir tai apsunkina VAS diagnostiką.

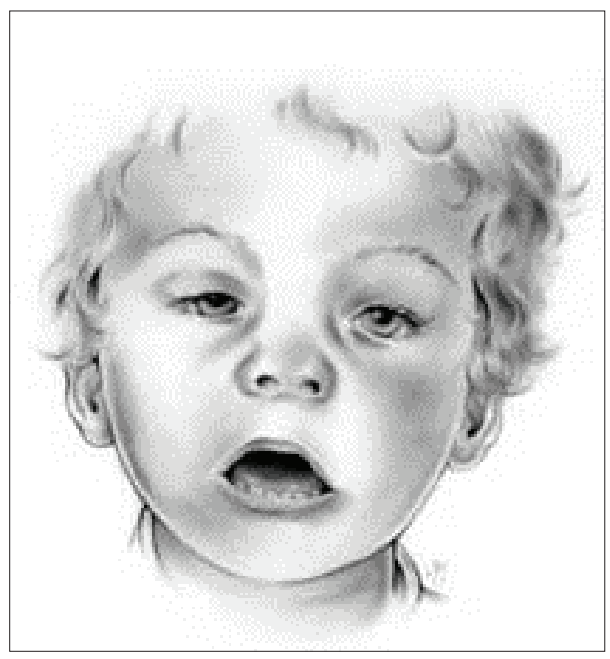

2 pav. Specifiniai veido bruožai esant VAS

VAS odontologo praktikoje. Reguliarūs apsilankymai pas odontologą ir burnos ligu profilaktika yra geriausias būdas užkirsti kelią dantų, dantenų ir periodonto problemoms atsirasti. Patartina vizitus skirti ramesniu dienos metu, kad pacientui nereiktų laukti. Gydymas turètų būti atliekamas tame pačiame kabinete, to pačio personalo, naudojant tokius pat instrumentus. Kiekvieną atliekamą veiksmą reikia tiksliai paaiškinti. Tokie pacientai dažniauiai yra suirzę, priešiški, nekooperatyvūs, sunku valdyti liežuvị, todèl jiems skiriamas ypatingas dèmesys.

Būtina tiksliai surinkti sisteminių ligų ir vartojamų vaistų anamnezę. Prieš pradedant gydymą, rekomenduojama pasitarti su pediatru ar terapeutu. Esant sutrikusiai nervų sistemai, gali prireikti anksiolitinių procedūrų, o vartojant kepenų fermentus - didesnio anestetikų kiekio. Taip pat reikia atkreipti demesị ị vaistus, pasišalinančius pro inkstus. Glomerulinès filtracijos greičiui (GFR) nukritus iki $50 \mathrm{ml} / \mathrm{min}$, reikètų sumažinti vaistų kieki ir pailginti vartojimo trukmę. Tokiems vaistams yra priskiriamas „Acyclovir“", „Aspirin“, aminoglikozidai, nesteroidiniai vaistai nuo uždegimo. Esant skausmui, rekomenduojama vartoti acetaminofeną.

Taip pat dažnai tokie pacientai neadekvačiai reaguoja ị tam tikrą stimuliaciją, pvz.: šviesą, garsą, lietimą. Norint sumažinti šviesos poveiki, galima naudoti akinius nuo saulès, o garsą - ausinukus.

Apie $80 \%$ vaikų, turinčių VAS, pasireiškia dantų - alveolinès ataugos problemos. Joms priskiriamas lūpos ir/ ar gomurio nesuaugimas, viršutinio ir apatinio žandikaulių hiperplazija ir hipoplazija, netaisyklingas sukandimas. Sutrinka dantų kaita - nuolatinis sąkandis formuojasi vyresniame amžiuje, nes vẻluoja pieninių dantų kritimas. Taip pat vystosi silpni kramtyme dalyvaujantys raumenys. Esant silpnam burnos žiediniui raumeniui (lot. m. orbicularis oris), pasunkejja maitinimas (sunku apžioti šaukštą ar šakutę, gerti pro šiaudelį), o silpnas žandinis raumuo (lot. $\mathrm{m}$. buccinator) nenukreipia maisto kramtymo kryptimi. Dèl veido deformacijų ir silpnų raumenų vyrauja kvėpavimas pro burną. Dèl to vystosi kserostomija, padidejja karieso 
rizika, dažnesnės dantenų ir periodonto ligos, SAŽS disfunkcija. Taip pat sutrinka normalus viršutinio žandikaulio vystymasis - formuojasi siauras aukštas gomurys. Tokiems pacientams ankščiau nei ịprastai reikia plèsti gomuri. Juos lydi ir kalbos problemos, todèl reikalinga ankstyva logopedo konsultacija [37-39].

Gydymas. Nėra jokių vaistų ar specifinio gydymo esant VAS. Protiniai ir fiziniai sutrikimai išlieka visą gyvenimą. Vaikams yra skiriamas ypatingas dèmesys, mokykloje mokosi pagal specialią programą. Tèvai yra paruošiami suprasti kitokị vaiko elgesị [25-27].

Prevencija. Alkoholio nevartojimas nėštumo metu ir ji planuojant yra vienintelis būdas apsaugoti vaiką nuo VAS. Skiriamos šios prevencijos kategorijos [28, 29]:

- Visuotinè prevencija. Jos tikslas supažinti visuomenę su alkoholio vartojimo néštumo metu pasekmèmis. Šiam tikslui pasiekti yra naudojamos įvairios priemonès: skelbimai, reklamos, lankstinukai, televizija, ispejjamosios etikètès ant alkoholinių gèrimų pakuočių. İsteigtos specialios organizacijos, kurios skleidžia informaciją apie žalingą alkoholio poveiki, pvz.: „The Arc“, „NOFAS“, „March of Dimes“. Tačiau labiausiai paplitusi „FASWORLD“ programa. Jos organizatoriai $2013 \mathrm{~m}$. rugsejjo 18-20 dienomis rengè pirmają Tarptautinę VAS Prevencijos konferenciją.

- Selektyvinè prevencija. Ji skirta moterims, kurios vartoja alkoholị néštumo metu. Vykdoma tokių néščiųų atranka ir joms skiriamos papildomos konsultacijos. Vienu iš tokios prevencijos pavyzdžių galima laikyti „FAS Screening" programą, vykdytą Vašingtone 1993-1998 m. Jos metu gimè 264 naujagimiai, iš kurių tik 5 turèjo VAS [34].

- Indikacinė prevencija. Ji taikoma néščiosioms, turinčioms didelę riziką susilaukti naujagimio, turinčio VAS, bei kurių anamnezèje užfiksuotas ankstesnis alkoholio vartojimas nëštumo metu. 1997 m. JAV buvo vykdyta "Seattle Birth to 3 Advocacy" programa. Šioje programoje dalyvavo 65 moterys, turinčios priklausomybę nuo alkoholio. Specialiai apmokytas personalas konsultavo kiekvieną moteri individualiai 3 metus. $60 \%$ tiriamujų nustojo vartoti alkoholi, $62 \%$ moteru toliau tęse programą, noredamos sumažinti riziką susilaukti naujagimio, turinčio VAS [35].

Prognozè. VAS prognozė priklauso nuo smegenų pažeidimo ir simptomų pasireiškimo laipsnio. Sunkiais atvejais naujagimis miršta per kelias pirmąsias savaites. Tačiau dažniausiai išgyvena ir turi liekamujų reiškinių visą gyvenimą. Jiems priskiriamas pirminis ir antrinis nedarbingumas. Pirminis nedarbingumas būna vaikui gimus dèl CNS pažeidimo, motinai vartojus alkoholį nèštumo metu. Tokiems vaikams sunkiau sekasi mokytis, sutelkti demesị, adaptuotis aplinkoje. Dažnai pasireiškia hiperaktyvumas, sensorinès integracijos sutrikimas [2,30]. Antrinis nedarbingumas pasireiškia gyvenimui bėgant dèl CNS pažeidimo, motinai vartojus alkoholį nèštumo metu. Šiems suaugusiems išryškejja protinis atsilikimas, todèl nesugeba gyventi savarankiškai, reikalinga nuolatinè priežiūra. Dažnos problemos su teisèsauga, kadangi jiems sunku kontroliuoti pyktį bei nusivylimą. Tokiais žmonėmis lengva manipuliuoti, jie dažnai itraukiami ị nusikalstamą veiklą. Taip pat jiems būdingas neadekvatus seksualinis elgesys, sunku sukurti šeimą, o moterims kyla gimdymo problemos. Dèl to jie jaučiasi vieniši. Trečdalis sergančiujų vartoja alkoholị, narkotikus. Pusei iš jų reikalingas gydymas nuo priklausomybès stacionare [31]. Vienos studijos duomenimis, buvo sekami 11 asmenų, turinčių VAS. Praejus 10 m., du tiriamieji buvo mirę, su vienu - prarastas kontaktas. Likę 8 tiriamieji turèjo augimo nepakankamumą ir dismorfiją. Moterims menarchè įvyko laiku, tačiau po jos padidejjo kūno svoris. Visiems pasireiškè protinis atsilikimas: 4 tiriamiesiemas reikalinga nuolatinè vaistų terapija, o likusiems - nuolatinè priežiūra [36].

\section{Apibendrinimas}

VAS yra visos visuomenès, o ne tik moterų problema. Jau nuo senų senovės alkoholis yra vyrų gèrimas ir svaiginimosi priemonè. Visose kultūrose, kuriose yra paplitęs alkoholio vartojimas, vyrai geria daugiau nei moterys. Savaime suprantama, kai moterys viešumoje geria per daug, jų alkoholizmas pastebimas daug greičiau nei vyrų. Galiausiai atsitinka taip, kad moterys slepia savo alkoholio vartojimą ir todèl pagalba joms suteikiama gana vélai.

\section{Literatūra}

1. Ulleland CN. The offspring of alcoholic mothers. Annals New York Academy of Sciences, 1972; 197: 167-169.

2. Streissguth A. Fetal Alcohol Syndrome: A Guide for Families and Communities. Baltimore: Brookes Publishing, 1997.

3. Ethen MK, Ramadhani TA, Scheuerle AE et al. ,Alcohol Consumption by Women Before and During Pregnancy“. Maternal and child health journal, March 2008; 13(2): 274-85.

4. Carlo WA. Fetal alcohol syndrome. In: Kliegman RM, Behrman RE, Jenson HB, Stanton BF, eds. Nelson Textbook of Pediatrics. 18th ed. Philadelphia, Pa: Saunders Elsevier; 2007:chap 100.2.

5. Cunningham FG, Leveno KJ, Bloom SL, et al. Teratology and medications that affect the fetus. In: Cunningham FG, Leveno KJ, Bloom SL, et al, eds. Williams Obstetrics. 23rd ed. New York, NY: McGraw-Hill; 2010:chap 14.

6. Effect of early exposure to ethanol on the protein and DNA contents of specific brain regions in the rat.Miller MW, Brain Res. 1996 Sep 23; 734(1-2):286-94.

7. Webster WS, Walsh DA, Lipson AH, McEwen SE. Teratogenesis after acute alcohol exposure in inbred and outbred mice. Neurobehav Toxicol. 1980; 2:227-34.

8. Webster WS, Walsh DA, Lipson AH, McEwen SE. Teratoge- 
nesis after acute alcohol exposure in inbred and outbred mice. Neurobehav Toxicol. 1980; 2:227-34.

9. Sequence of developmental alterations following acute ethanol exposure in mice: craniofacial features of the fetal alcohol syndrome.Sulik KK, Johnston MCAm J Anat. 1983 Mar; 166(3):257-69.

10. Fetal alcohol syndrome: embryogenesis in a mouse model. Sulik KK, Johnston MC, Webb MA Science. 1981 Nov 20; 214(4523):936-8.

11. Prenatal exposure to ethanol alters the postnatal development and transformation of radial glia to astrocytes in the cortex.Miller MW, Robertson SJ Comp Neurol. 1993 Nov 8; 337(2):253-66.

12. Transforming growth factor beta 1 modulates cell migration in rat cortex: effects of ethanol.Siegenthaler JA, Miller MW,Cereb Cortex. 2004 Jul; 14(7):791-802.

13. Ethanol-induced apoptotic neurodegeneration and fetal alcohol syndrome.Ikonomidou C, Bittigau P, Ishimaru MJ, Wozniak DF, Koch C, Genz K, Price MT, Stefovska V, Hörster F, Tenkova T, Dikranian K, Olney JW, Science. 2000 Feb 11; 87(5455):1056-60.

14. Pascual-Leone, A., Freitas, C., Oberman, L., Horvath, J. C., Halko, M., Eldaief, M. et al. Characterizing brain cortical plasticity and network dynamics across the age-span in health and disease with TMS-EEG and TMS-fMRI. Brain Topography, 2011; 24, 302-315.

15. Fetal alcohol syndrome: diagnosis, epidemiology, prevention, and treatment By Kathleen R. Stratton, Cynthia J. Howe, Frederick C. Battaglia, Institute of Medicine (U.S.). Division of Biobehavioral Sciences and Mental Disorders. Committee to Study Fetal Alcohol Syndrome, National Institute on Alcohol Abuse and Alcoholism (U.S.), 1996; 82 - 100.

16. Institute of Medicine (IOM), Stratton, K.R., Howe, C.J., \& Battaglia, F.C. (1996). Fetal Alcohol Syndrome: Diagnosis, Epidemiology, Prevention, and Treatment. Washington, DC: National Academy Press. ISBN 0-309-05292-0.

17. Astley SJ (2004). Diagnostic Guide for Fetal Alcohol Spectrum Disorders: The 4-Digit Diagnostic Code. Seattle: University of Washington. PDF available at FAS Diagnostic and Prevention Network. Retrieved on 2007-04-11.

18. Fetal Alcohol Syndrome: Guidelines for Referral and Diagnosis (PDF). CDC (July 2004). Retrieved on 2007-04-11 Archived September 26, 2007 at the Wayback Machine.

19. Chudley A, Conry J, Cook J et al. (2005). „Fetal alcohol spectrum disorder: Canadian guidelines for diagnosis". CMAJ 172 (5 Suppl): S1-S21. doi:10.1503/cmaj.1040302. PMC 557121. PMID 15738468. Retrieved 2007-04-10.

20. FAS facial features. FAS Diagnostic and Prevention Network, University of Washington. Retrieved on 2007-04-10.

21. Institute of Medicine (U.S.). Fetal Alcohol Syndrome: Diagnosis, Epidemiology, Prevention, and Treatment. Washington D.C.: National Academy Press, 1996.

22. Streissguth A and Kanton J (Eds.). The Challenge of Fetal Alcohol Syndrome: Overcoming Secondary Disabilities. Seattle, University of Washington Press, 1997.
23. Coggins TE, Friet T, Morgan T, Wikstrom M: Washington State FAS DPN: Communicative Behavior Assessment. Seattle, WA: University of Washington Publication Services, 1998.

24. Riikonen RS. Difference in susceptibility to teratogenic effects of alcohol in discordant twins exposed to alcohol during the second half of gestation. Pediatric Neurology 1994;11:332-336.

25. Treatment for Fetal Alcohol Syndrome, Protective Factors Can Lessen Secondary Conditions, By Buddy T, About.com Guide, Updated July 09, 2010.

26. Buxton B. (2005). Damaged Angels: An Adoptive Mother Discovers the Tragic Toll of Alcohol in Pregnancy. New York: Carroll \& Graf. ISBN 0-7867-1550-2.

27. Carlo WA. Fetal alcohol syndrome. In: Kliegman RM, Behrman RE, Jenson HB, Stanton BF, eds. Nelson Textbook of Pediatrics. 18th ed. Philadelphia, Pa: Saunders Elsevier; 2007:chap 100.2.

28. Centers for Disease Control and Prevention (CDC). Alcohol use among women of childbearing age-United States, 1991-1999. Morbidity and Mortality Weekly Reports, April 5, 51(13):273-276, 2002a.

29. Chang G, Goetz MA. Wilkins-Haug L and Berman S. A brief intervention for prenatal alcohol use: An in-depth look. Journal of Substance Abuse Treatment 2000;18:365-369.

30. Streissguth AP, Barr HM, Kogan J \& Bookstein FL. (1996). Understanding the occurrence of secondary disabilities in clients with fetal alcohol syndrome (FAS) and fetal alcohol effects (FAE): Final report to the Centers for Disease Control and Prevention on Grant No. RO4/CCR008515 (Tech. Report No. 96-06). Seattle: University of Washington, Fetal Alcohol and Drug Unit.

31. Abkarian GG. Communication effects of prenatal alcohol exposure. Journal of Communication Disorders, 1992; 25 : 221-240.

32. Lietuvos statistikos departamentas. „Alkoholinių gėrimų suvartojimas. Požymiai: administracinė teritorija,statistiniai rodikliai ir metai“", 2011.

33. Lietuvos statistikos departamentas. „Socialinès rizikos šeimos metų pabaigoje. Požymiai: administracinè teritorija, statistiniai rodikliai ir metai“, 2011.

34. Fetal alcohol syndrome prevention in Washington State: evidence of success, Susan J. Astley Center on Human Development and Disability, Department of Epidemiology, School of Public Health and Community Medicine, University of Washington, Seattle WA, USA, 2004.

35. Fetal Alcohol Syndrome Prevention Research, Janet R. Hankin, Ph.D. is a professor in the Department of Sociology, Wayne State University, Detroit, Michigan, 2002.

36. Natural history of the fetal alcohol syndrome: 10 - year follow up of eleven patiens, AnnPytkowicz Streissguth, SterlingKeith Clarren, KennethLyons Jones.

37. Little JW, Falace DA, Miller CS, Rhodus NL. Dental Management of the Medically Compromised Patient, Sixth Edition. St. Louis: CV Mosby Co. 2002; 181-83, 468-75, 419-22.

38. Eustace LW, Kang D-H, Coombs D. Fetal alcohol syndrome: a 
growing concern for health care professionals. J Obstet Gynecol Neonatal Nurs 2003; 32:215-21.

39. Churach MW, Abel EL. Fetal alcohol syndrome. Hearing, speech, language, and vestibular disorders. Obstet Gynecol Clin North Am 1998; 25(1):85-97.

\section{FETAL ALCOHOL SYNDROME}

\section{Bradulskaitė}

Key words: fetal alcohol syndrome, alcohol during pregnancy, growth disorder, specific facial features, brain abnormalities.

\section{Summary}

The purpose of this article is to attract attention to dangers of alcohol consumption during pregnancy and to raise more inte- rest to the impact of psychoactive substances during pregnancy. Physicians, public health professionals are urged to contribute to public enlightenment, whereas politicians to make decisions that would bind alcohol manufacturers to adequately inform customers about health risks caused by their products. There are presented factors causing fetal alcohol syndrome, epidemiology, diagnostic principles, and symptoms, focusing on odontological aspects, prevention and prediction.

Correspondence to: bradulskaite@yahoo.com

Gauta 2013-08-13 